\title{
DONGENG DALAM MEMBENTUK KARAKTER ISLAMI ANAK
}

\author{
Zulfitria \\ zulfitria81@gmail.com \\ Teknologi Pendidikan, Fakultas Ilmu Pendidikan, Universitas Muhammmadiyah \\ Zainal Arif \\ zarifpambon@gmail.com \\ Pendidikan Agama Islam, Fakultas Agama Islam, Universitas Muhammadiyah \\ Abidah \\ maepambon@gmail.com \\ TK Aisyiyah Bustanul Athfal Cendoro Palang Tuban Jawa Timur \\ Arifah \\ arifahpambon@gmail.com \\ Madrasah Ibtidaiyah Muhammadiyah Jabung Laren Lamongan Jawa Timur
}

\begin{abstract}
Abstrak
Dilatar belakangi oleh era millenium sekarang ini, bahwa budaya mendongeng telah dianggap kuno dan mulai ditinggalkan. Dongeng merupakan cerita yang mengandung nilainilai moral dan sosial yang berguna untuk membentuk karakter anak. Pembentukan karakter anak dapat dilakukan di lingkungan pembelajaran sekolah dan lingkungan rumah atau keluarga. Strategi pembentukan karakter anak dilakukan dengan pemberian contoh, pembiasaan membaca serta mendengarkan dongeng, dan penciptaan lingkungan baca yang mendukung. Dongeng salah satu media yang dapat menyampaikan berbagai pesan dan menumbuhkan minat baca anak yang dibentuk sejak sini. Dongeng bagian dari budaya rakyat Indonesia. Pengaruh dongeng yang besar terhadap moralitas dan karakter anak-anak sangat mendukung dijadikannya dongeng sebagai cerita pendukung pendidikan karakter. Pemerintah Indonesia juga telah mencanangkan kebijakan gerakan nasional Penguatan Pendidikan Karakter (PPK) dengan berupaya membudayakan mendongeng untuk meningkatkan kecerdasan dalam membentuk karakter bangsa yang unggul, tangguh, dan berbudaya. Penelitian ini menggunakan penelitian kualitatif kajian Pustaka. Kesimpulan dari penelitian ini adalah mendongeng bisa dilakukan oleh orang tua dan guru sebagai pendidik dalam membentuk karakter anak agar menjadi lebih baik.
\end{abstract}

\section{Kata kunci:dongeng, karakter, Anak}

Abstract
Backgrounded by the current millennium era, that storytelling culture has been considered
ancient and began to be abandoned. Fairy tales are stories that contain moral and social
values that are useful for shaping the character of children. The formation of children's
characters can be done in the school learning environment and home or family environment.
The strategy for forming children's characters is done by giving examples, reading and
listening to fairy tales, and creating a supportive reading environment. Fairytale is one of the
media that can convey a variety of messages and foster children's reading interest formed
since here. Fairy tales are part of Indonesian folk culture. The great influence of fairy tales
on the morality and character of children strongly supports the making of fairy tales as
supporting stories of character education. The Government of Indonesia has also launched a
national movement policy on Strengthening Character Education (PPK) by trying to civilize 
storytelling to improve intelligence in shaping the character of a superior, resilient, and cultured nation. This study uses a qualitative study of literature. The conclusion of this research is that storytelling can be done by parents and teachers as educators in shaping the character of children to be better.

Keywords: fairy tales, characters, children

\section{A. Pendahuluan}

Kemajuan suatu bangsa yang cerdas pada hakikatnya dimulai dari pengembangan di bidang pendidikan. Hal ini ditandai dengan turunnya firman Allah SWT yaitu:

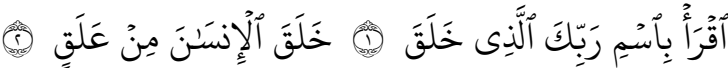

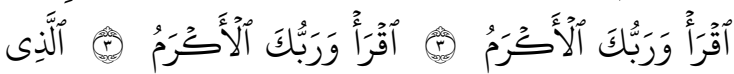

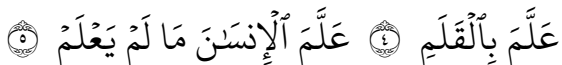

Artinya: "Bacalah dengan (menyebut) nama Tuhan-mu yang menciptakan, Dia telah menciptakan manusia dari segumpal darah. Bacalah, dan Tuhanmu-lah Yang Maha mulia, Yang mengajar (manusia) dengan pena, Dia mengajar manusia apa yang tidak diketahuinya",

Dalam ayat tersebut Allah SWT telah mengisyaratkan kepada seluruh umat manusia untuk banyak belajar berbagai hal untuk dapat membaca tanda-tanda kekuasaan Allah SWT dengan aktivitas membaca. Membaca merupakan jendela dunia. Membaca sangat penting dilakukan bagi orang yang suka mendongeng. Di era millennium ini, aktivitas mendongeng sudah jarang dilakukan orangtua terhadap anak-anak. Malah sebaliknya anak lebih senang bermain games ataupun handphone dibandingkan membaca. Kebiasaan masyarakat Indonesia dalam membaca dan menulis masih terbilang sangat rendah. Rendahnya minat baca masyarakat Indonesia ini makin menyebabkan kualitas

\footnotetext{
${ }^{1}$ Departemen Agama. 1997. Al-Qur'an dan Terjemahannya. Jakarta: Surya Cipta Aksara, h.597
}

dan mutu pendidikan di Indonesia juga hanya jalan di tempat (stagnan) dan cenderung mundur. Berdasarkan beberapa penelitian, penyebab rendahnya budaya baca ini karena masyarakat Indonesia lebih suka menonton televisi (TV), mendengarkan radio, dan bergelut pada dunia maya (internet dan media sosial) dibandingkan membaca buku. Oleh karena itu, dongeng bisa dijadikan sebagai media untuk membentuk karakter anak karena memiliki nilai budi pekerti yang bisa dipelajari oleh anak ${ }^{2}$. Mendongeng bisa dilakukan oleh orang tua maupun guru. Dengan mendongeng orang tua dan guru dapat mengasah potensi intelektual yang berhubungan dengan kecerdasan, potensi social, potensi moral, potensi imaginal, potensi emosional, potensi spiritual dan potensi lingual. Serta dapat mendekatkan kita pada siswa dan membangun jalannya komunikasi terhadap siswa ${ }^{3}$

Dikisahkan bahwa Nabi Muhammad SAW dalam memberikan pelajaran kepada para sahabat seringkali menggunakan metode cerita tentang halhal yang berkaitan dengan kehidupan dan kejadian-kajadian masa lalu. Penggunaan metode itu dianggap akan lebih membekas dalam jiwa orang-orang yang mendengarkannya serta menarik perhatian.

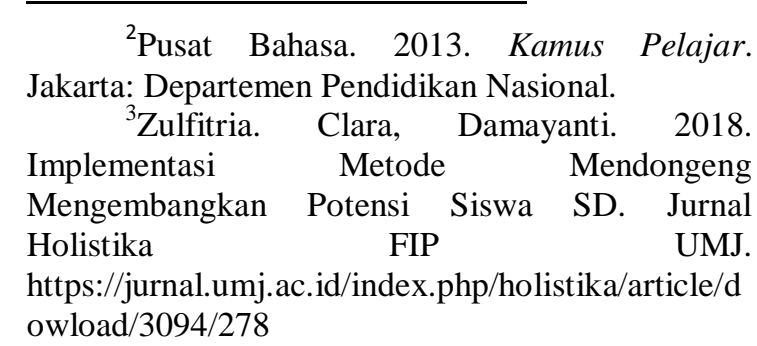


Dengan demikian pembelajaran mendongeng diharapkan membentuk karakter anak tentang kejadian masa lalu sebagai pelajaran untuk masa sekarang.

\section{B. Metode Penelitian}

Metode penelitian digunakan metode penelitian kualitatif, berupa kajian Pustaka.

\section{Hasil Dan Pembahasan}

\section{Pembentukan Karakter Islam Anak}

Anak adalah generasi penerus bangsa dan agama. Di zaman yang serba modern ini terkadang membuat anak terjebak pada rutinitas yang serba instan. Hal tersebut membuat anak kehilangan figure yang perlu didengar dan ditiru serta menghilangkan karakter baik anak. Anak mempunyai daya imajinasi yang lebih beragam dari pada orang dewasa. Terlebih lagi ketika anak-anak bermain peran, yaitu memerankan tokoh dari sebuah cerita maupun dongeng, maka imajinasinya akan menghidupkan daya fantasinya sehingga ia seolah-olah benar-benar menjadi sosok yang diperankannya tersebut. Selain itu, anak juga mempunyai rasa ingin tahu yang tinggi. Mendongeng merupakan salah satu yang dapat mengembangkan kreatifitas, imajinasi dan karakter anak.

Undang-undang No. 20 tahun 2003 tentang Sistem Pendidikan Nasional menyatakan bahwa "Pendidikan nasional berfungsi mengembangkan kemampuan dan membentuk watak serta peradaban bangsa yang bermartabat dalam rangka mencerdaskan kehidupan bangsa, bertujuan untuk mengembangkan potensi peserta didik agar menjadi manusia yang beriman dan bertakwa kepada Tuhan Yang Maha Esa, berakhlak mulia, sehat, berilmu, cakap, kreatif, mandiri, dan menjadi warga negara yang demokratis serta bertanggung jawab."4. Pembangunan karakter sudah menjadi amanat dalam pendidikan dan menjadi kewajiban bersama untuk mewujudkan Indonesia yang berakhlak, bermoral, dan beretika

Dunia pendidikan harus mampu menjawab tantangan saat ini. Guru dituntut berkreasi dengan memanfaatkan kecanggihan teknologi sebagai sumber belajar, media belajar, dan proses kegiatan belajar-mengajar. Guru era millenial harus melek IT dan teknologi. Tidak ada alasan masalah guru muda atau tua, semuanya mempunyai tanggungjawab yang sama dalam mencerdaskan kehidupan bangsa sesuai amanat UUD 1945. Era millenial bukan menjadi suatu hambatan, namun bagaimana guru menyikapi era millenial ini menjadi tantangan kearah kemajuan pendidikan. Pendidikan karakter merupakan bagian dari pendidikan nilai (values education) yang ditanamkan sejak bangku sekolah. Sebab ke depan, sekolah tidak hanya bertanggung jawab dalam mencetak peserta didik yang unggul dalam ilmu penggetahuan dan teknologi tetapi juga memiliki pribadi yang berkarakter dan berkepribadian sebagaimana dituntut dalam tujuan pendidikan nasional. Upaya menanamkan nilai-nilai karakter pada anak di era millenial bisa dilakukan dalam pendidikan karakter. Pendidikan karakter merupakan pendidikan yang mengajarkan hakikat dalam ketiga ranah cipta, rasa, dan karsa mendukung perkembangan sosial, emosional, dan etis siswa ${ }^{5}$. Pendidikan karakter merupakan bagian dari pendidikan nilai (values education) yang ditanamkan sejak bangku sekolah. Sebab ke depan,

\footnotetext{
${ }^{4}$ Depdiknas. Undang-Undang Republik Indonesia Nomor 20 Tahun 2003 Tentang Sistem Pendidikan Nasional, h.5

${ }^{5}$ Isbell, R., Sobol, J., Lindauer, L \& Lowrance. 2014. "The Effects of Storytelling and Story Reading on The Oral Language Complexity And Story Comprehension Of Young Children". Early childhood education journal, h.59
} 
sekolah tidak hanya bertanggung jawab dalam mencetak peserta didik yang unggul dalam ilmu penggetahuan dan teknologi tetapi juga memiliki pribadi yang berkarakter dan berkepribadian sebagaimana dituntut dalam tujuan pendidikan nasional.

Dikisahkan dalam kandungan AlQur'an surat Luqman ayat 12-19 yang berisi tentang kisah Luqman. Kandungan dalam Al-Qur'an surat Lukman, Allah SWT berfirman: "Dan ingatlah ketika lukman berkata kepada anaknya, ketika dia memberi pelajaran kepadanya, "wahai anakku, janganlah engkau mempersekutukan Allah, sesungguhnya mempersekutukan (Allah) adalah benarbenar kezaliman yang besar",6

Nilai pendidikan yang terkandung dalam surah ini, yaitu bagaimana seharusnya menjadi orang tua dalam berikan pembelajaran kepada anak dengan keteladanan. Keteladanan bisa dilakukan dengan berkisah dalam mendongeng untuk membentuk karakter anak.

Pendidikan karakter dapat dilakukan dengan berbagai model, yaitu model pembiasaan dan keteladanan, pembinaan disiplin, hadiah dan hukuman, pembelajaran kontekstual, bermain peran, dan pembelajaran partisipatif ${ }^{7}$.

Pendidikan karakter bukanlah berupa materi yang hanya bisa dicatat dan dihafalkan serta tidak dapat dievaluasi dalam jangka waktu yang pendek, tetapi pendidikan karakter merupakan sebuah pembelajaran yang teraplikasi dalam semua kegiatan siswa baik di sekolah, lingkungan masyarakat dan di lingkungan rumah melalui proses pembiasaan,

${ }^{6}$ Departemen Agama. 1997. Al-Qur'an dan Terjemahannya. Jakarta: Surya Cipta Aksara, h.412.

${ }^{7}$ Mulyasa, E. 2012. Manajemen Pendidikan Karakter. Jakarta: Bumi Aksara. [9] Nurhadi, dkk. 2010. Bahasa Indonesia. Bandung: Erlangga, h.98. keteladanan, dan dilakukan secara berkesinambungan. Oleh karena itu keberhasilan pendidikan karakter ini menjadi tanggung jawab bersama antara guru, masyarakat dan orangtua. Dalam rangka memperkuat pelaksanaan pendidikan karakter, ada 18 nilai-nilai dalam pengembangan pendidikan budaya dan karakter bangsa yang dibuat oleh Diknas. 18 nilai-nilai dalam Pendidikan karakter tersebut adalah:1) Religius; 2) Jujur; 3) Toleransi;4) Disiplin; 5) Kerja Keras; 6) Kreatif; 7) Mandiri; 8) Demokratis; 9) Rasa Ingin Tahu; 10) Semangat Kebangsaan; 11) Cinta Tanah Air; 12)Menghargai Prestasi; 13) Bersahabat/Komunikatif ; 14) Cinta Damai;15) Gemar Membaca; 16) Peduli Lingkungan;17) Peduli Sosial; dan 18) Tanggung Jawab.

Adapun materi yang diajarkan dalam rangka karakter Islami yang selalu diberikan di sekolah pada setiap harinya setelah mendongengkan kepada siswa adalah sebagai berikut:

1) Membiasakan mengajarkan anak terbiasa berdoa, bersyair dan menyanyikan lagu-lagu keagamaan

2) Membiasakan mengajarkan anak terbiasa melakukan ibadah sesuai dengan aturan menurut keyakinannya

3) Membiasakan mengajarkan anak mengenal dan menyayangi ciptaan Tuhan

4) Membiasakan mengajarkan anak terbiasa berperilaku sopan santun

5) Membiasakan mengajarkan anak membedakan perbuatan yang benar dan salah

6) Membiasakan mengajarkan anak terbiasa untuk disiplin

7) Membiasakan mengajarkan anak terbiasa bersikap dan berperilaku saling hormat-menghormati

8) Membiasakan mengajarkan anak terbiasa bersikap ramah 
9) Membiasakan mengajarkan anak menunjukkan sikap kerjasama dan persatuan

10) Membiasakan mengajarkan anak dapat menunjukkan rasa percaya diri

11) Membiasakan mengajarkan anak terbiasa menunjukkan kepedulian

12) Membiasakan mengajarkan anak terbiasa menjaga kebersihan diri dan mengurus dirinya sendiri

13) Membiasakan mengajarkan anak terbiasa menjaga lingkungan

14) Membiasakan mengajarkan anak menghemat pemakaian air dan listrik.

Maka pentingnya pendidikan karakter sejatinya memberikan motivasi serta pencerahan bagi pemerintah, para pendidik, insan akademik serta stakeholder Pendidikan pada umumnya untuk segera sadar dan bangkit berupaya mencari solusi agar pendidikankarakter ini dapat diimplementasikan dengan segera di sekolah maupun rumah.

\section{Pendidikan Berbasis Dongeng}

Pendidikan bagi kehidupan manusia merupakan kebutuhan yang mutlak yang harus dipenuhi sepanjang hayat. Tanpa pendidikan sama sekali mustahil suatu kelompok manusia dapat hidup berkembang dengan cita-cita untuk maju, sejahtera, dan bahagia menurut konsep pandangan hidupnya ${ }^{8}$. Karakter bangsa tidak terjadi dengan sendirinya, melainkan harus dibentuk, dilatih, dan dikelola secara bertahap. Pembentukan karakter bangsa merupakan tanggung jawab bersama, guru, tutor dan seluruh komponen bangsa untuk berkomitmen membentuk, membangun dan mempertahankannya. Pendidikan karakter merupakan upaya yang melibatkan semua pihak baik keluarga (informal), sekolah dan lingkungan sekolah, serta masyarakat luas.

\footnotetext{
${ }^{8}$ Nasution, 1995. Sosiologi Pendidikan. Jakarta: Bumi Aksara, h.83.
}

Pembentukan dan pendidikan karakter tidak akan berhasil selama antar lingkungan pendidikan tersebut tidak ada kesinambungan dan keharmonisan. Mendidik karakter anak bukanlah suatu perkara yang mudah. Orang tua yang keliru dalam mengasuh anaknya akan menghasilkan "produk" anak yang membangkang, tidak dapat menghormati orang lain, tidak mengenal tata krama atau sopan santun, dan lain-lain. Orang tua yang memiliki kesibukan yang sangat padat dipastikan akan mengabaikan anaknya dan tidak memiliki waktu untuk mendengarkan apa kata hati dan keinginan mereka.

Agama Islam yang dibawa oleh Nabi Muhammad SAW dalam salah satu sabdanya mengisyaratkan bahwa kehadirannya di muka bumi ini membawa misi pokok untuk menyempurnakan akhlak manusia yang mulia. Nabi SAW benarbenar menjadi panutan dan teladan bagi umatnya dan bagi setiap manusia yang mau menjadi manusia berkarakter atau berakhlak mulia. Pengakuan akan akhlak Nabi SAW yang sangat agung bukan hanya dari manusia, tetapi dari Allah SWT seperti dalam firman-Nya dalam Surat AlAhzab [33]: 21, "Sesungguhnya telah ada pada (diri) Rasulullah itu suri teladan yang baik bagimu (yaitu) bagi orang yang mengharap (rahmat) Allah dan (kedatangan) hari kiamat dan dia banyak menyebut Allah." "9

Di era millennium ini, aktivitas mendongeng sudah jarang dilakukan orangtua terhadap anak-anak mereka. Maupun sebaliknya anak lebih senang bermain games atapun HP dibandingkan membaca maupun mendengarkan cerita/dongeng. Sejak zaman dahulu dongeng sudah dikenal oleh nenek moyang kita. Dongeng dijadikan sebagai media

${ }^{9}$ Departemen Agama. 1997. Al-Qur'an dan Terjemahannya. Jakarta: Surya Cipta Aksara, h.420. 
dalam menanamkan nilai-nilai sosial maupun nilai kemanusiaan. Dongeng biasa di luar negeri dengan sebutan folklore, merupakan cerita rakyat yang asalnya adalah sebuah kisah yang dituturkan dari mulut ke mulut dengan harapan bahwa sang anak bisa memetik nilai-nilai kebajikan dari cerita itu. Tetapi saat ini, seiring dengan perkembangan teknologi digital yang pesat, anak-anak milenial zaman sekarang memandang dongeng sebagai sesuatu yang kuno.

Era digital seperti sekarang ini, dua pertiga dari orangtua dan kakek-nenek merasa bahwa teknologi modern sudah menghilangkan tradisi mendongeng. Jika kejadian ini terus berlanjut, maka anakanak akan jauh dari akhlak, moral, dan etika baik dengan hilangnya karakter anak Indonesia ${ }^{10}$.Rendahnya minat baca pada anak juga berpengaruh belum ditangani sepenuhnya oleh keluarga, sekolah, masyarakat dan negara jika teruss berlanjut maka bangsa ini akan merugi, karena anakanak yang seharusnya menjadi garda terdepan untuk menghadapi globalisasi ditingkat ASEAN dan dunia. Oleh karena itu dongeng berpotensi memberikan sumbangsih besar bagi anak untuk memiliki jati diri yang jelas pribadi yang berkarakter. Dongeng dapat digunakan sebagai sarana mewariskan nilai-nilai luhur kepribadian, secara umum dongeng dapat membantu anak menjalani masa tumbuh kembangnya. Anak-anak dapat memahami pola drama kehidupan melalui tokoh dongeng. Melalui dongeng, anak-anak akan terlibat dalam alur cerita dongeng dalam hal ini anak-anak menumbuh kembangkan intelektualitasnya.

${ }^{10}$ Kartikawati, Eny. 2012. Hanya 33\% Orangtua yang Masih Sempat Mendongeng untuk Anak,(Online),http://wolipop.detik.com/read/2012/1 0/10/070850/2058848/857/hanya-33-orangtuayang-masih-sempat-mendongeng-untuk-anak, diakses 1 Maret 2020, h.3
Model pebelajaran berbasis dongeng dapat dijadikan sebagai media pembentuk kepribadian dan moralitas anak usia dini, melalui metote dongeng akan memberikan pengalaman belajar bagi anak usia dini. Metode dongeng memiliki sejumlah aspek yang diperlukan dalam perkembangan kejiwaan anak, memberi wadah bagi anak untuk belajar berbagai emosi dan perasaan dan belajar nilai-nilai moral. Anak akan belajar pada pengalaman-pengalaman sang tokoh dalam dongeng, setelah itu memilah mana yang dapat dijadikan panutan olehnya sehingga membentuknya menjadi moralitas yang dipegang sampai dewasa Dongeng adalah cerita rekaan, khayal yang dianggap tidak benar-benar terjadi, terdapat beberapa aspek didalamnya yaitu aspek intelektual, aspek kepekaan, kehalusan budi, emosi, seni, fantasi dan imajinasi, tidak hanya mengutamakan otak kiri, tapi juga otak kanan ${ }^{11}$

Dilihat dari isinya dongeng dibedakan menjadi 5 macam yaitu: (1) Dongeng yang lucu Contoh: Dongeng Abu Nawas; (2) Fabel, fabel merupakan cerita pendek atau dongeng yang memberikan pendidikan moral yang menggunakan binatang sebagai tokohnya. Contoh: Dongeng kancil dan harimau; (3) Legenda, adalah: "Cerita yang isinya tentang asalusul suatu daerah". Contoh: Asal mula Danau Toba; (4) Sage, yaitu dongeng yang mengandung unsur sejarah. Contoh: Panji semiring; (5) Mite, sebagai: "dongeng yang berhubungan dengan kepercayaan masyarakat, Contoh: Nyai Loro Kid ${ }^{12}$ Dongeng merupakan salah satu cara yang efektif untuk mengembangkan aspek-aspek kognitif (pengetahuan), afektif (perasaan), sosial, dan aspek kognitif (penghayatan)

\footnotetext{
${ }^{11}$ Asfandiyar, Andi Yudha. 2010. Cara Pintar Mendongeng. Bandung: Mizan, h.95

${ }^{12}$ Parkin. 2014. Tales For Change: Using Storytelling To Develop People And Organization. Great Britain: Biddle's., h.75.
} 
anak-anak. Dongeng memiliki potensi untuk memperkuat imajinasi, memanusiakan individu, meningkatkan impati dan pemahaman, memperkuat nilai dan etika, dan merangsang proses pemikiran kritis dan kreatif. Bagi anakanak, duduk manis menyimak penjelasan dan nasehat merupakan sesuatu yang tidak menyenangkan. Sebaliknya, duduk berlama-lama menyimak cerita atau dongeng adalah aktivitas yang mengasyikkan ${ }^{13}$.

Manfaat dongeng manfaat mendongeng diantaranya:

1) Mengasah Otak kanan siswa

2) Jembatan Komunikasi Yang Efektif Bagi Guru Dan Siswa

3) Jembatan Komunikasi Yang Baik Antara Orang Tua Dan Siswa

4) Menghaluskan Budi Pekerti Siswa

5) Sumber Inspirasi Yang Baik Bagi Siswa

6) Membangun Mental Yang Mengajarkan Siswa Merangkai Kata

7) Membantu Siswa Belajar

8) Melatih Kemampuan Berbahasa Siswa

9) Dongeng Adalah Guru Yang Baik

10) Melatih Siswa Berfikir Sistematis

11) Mendorong Siswa Mencintai Buku ${ }^{14}$ Indonesia adalah negara yang kaya akan dongeng, khususnya dongeng untuk anak-anak. Masing-masing wilayah di Indonesia memiliki koleksi dongeng yang memanfaatkan potensi alam sekitar, supaya karakter anak dapat lebih terbangun. Hal ini disebabkan oleh kemasan dongeng yang merupakan perpaduan antara unsur hiburan dengan pendidikan dapat membentuk karakter pada anak era millennium.

Dengan mendongeng orang tua dan guru dapat mengasah potensi intelektual yang berhubungan dengan kecerdasan,

\footnotetext{
${ }^{13}$ Musfiroh, Tadkirotun, 2010. Cerita Untuk Anak Usia Dini. Yogyakarta: Tiara Wacana, h.64.

${ }^{14}$ Hendri. 2013. Pendidikan Karakter Berbasis Dongeng. Bandung. Simbiosa Rekatama Media, h.34.
}

potensi social, potensi moral, potensi imaginal, potensi emosional, potensi spiritual dan potensi lingual. Serta dapat mendekatkan kita pada siswa dan membangun jalannya komunikasi terhadap siswa $^{15}$.

\section{Simpulan}

Pendidikan karakter anak lebih menekankan pada habit atau kebiasaan yang terus menerus dipraktekkan dan dilakukan. Pendidikan merupakan suatu usaha dimana adanya kesadaran untuk mengembangkan potensi diri dalam memahami suatu pengetahuan untuk dapat dimengerti. Pendidikan sangat penting diterapkan pada anak. Pembentukan karakter sangat dipengaruhi oleh keadaan lingkungan, sehingga lingkungan memiliki peranan yang cukup besar dalam membentuk jati diri dan perilaku peserta didik. Pembentukan karakter melalui pendidikan Al-Quran yang berkualitas (membaca, mengetahui, dan memahami nilai-nilai yang terkandung di dalamnya) sangat perlu dan tepat serta mudah dilakukan secara berjenjang oleh setiap lembaga secara terpadu melalui manajemen yang baik. Para pendidik harus lebih bijaksana dalam menjabarkan nilainilai Al-Quran ke dalam program-program untuk dituangkan dalam rencana-rencana pembangunan manusia seutuhnya melalui proses pembelajaran. Hal itu harus dibarengi dengan pembiasaan dan keteladanan, melakukan pembinaan disiplin, memberi hadiah dan hukuman, pembelajaran kontekstual, bermain peran, dan pembelajaran partisipatif. Pembelajaran dongeng bisa memberikan

\begin{tabular}{|c|c|c|}
\hline $\begin{array}{l}{ }^{15} \text { Zulfitria. } \\
\text { Implementasi }\end{array}$ & $\begin{array}{l}\text { Clara, } \\
\text { Metode }\end{array}$ & $\begin{array}{l}\text { Damayanti. } \\
\text { Mend }\end{array}$ \\
\hline Mengembangkan & Potensi & Siswa SD. \\
\hline Holistika & FIP & UMJ, \\
\hline
\end{tabular}


kebutuhan tersebut kepada anak agardapat membentuk karakter siswa yang lebih baik.

\section{DAFTAR PUSTAKA}

Asfandiyar, Andi Yudha. 2010. Cara Pintar Mendongeng. Bandung: Mizan.

Depdiknas. Undang-Undang Republik Indonesia Nomor 20 Tahun 2003 Tentang Sistem Pendidikan Nasional. Departemen Agama. 1997. Al-Qur'an dan Terjemahannya. Jakarta: Surya Cipta Aksara.

Hendri. 2013. Pendidikan Karakter Berbasis Dongeng. Bandung. Simbiosa Rekatama Media

Isbell, R., Sobol, J., Lindauer, L \& Lowrance. 2014. "The Effects of Storytelling and Story Reading on The Oral Language Complexity And Story Comprehension Of Young Children". Early childhood education journal.

Kartikawati, Eny. 2012. Hanya 33\% Orangtua yang Masih Sempat Mendongeng untuk Anak,(Online),http://wolipop.detik.co $\mathrm{m} / \mathrm{read} / 2012 / 10 / 10 / 070850 / 2058848 /$ 857/hanya-33-orangtua-yang-masihsempat-mendongeng-untuk-anak, diakses 1 Maret 2020.

Mulyasa, E. 2012. Manajemen Pendidikan Karakter. Jakarta: Bumi Aksara. [9] Nurhadi, dkk. 2010. Bahasa Indonesia. Bandung: Erlangga

Musfiroh, Tadkirotun, 2010. Cerita Untuk Anak Usia Dini. Yogyakarta: Tiara Wacana,

Nasution, 1995. Sosiologi Pendidikan. Jakarta: Bumi Aksara.

Parkin. 2014. Tales For Change: Using Storytelling To Develop People And Organization. Great Britain: Biddle's.
Pusat Bahasa. 2013. Kamus Pelajar. Jakarta: Departemen Pendidikan Nasional.

Soelistyrini, Dwi. 2011. Nilai Moral dalam Cerita Rakyat sebagai Sarana Pendidikan Budi Pekerti, (Online), http://ki demang.com/kbj5/index.php/makala h-komisi-b/1147-13-nilai-moraldalam-cerita-rakyat-sebagai-saranapendidikan-budi-pekerti

Zulfitria. Clara, Damayanti. 2018. Implementasi Metode Mendongeng Mengembangkan Potensi Siswa SD. Jurnal Holistika FIP UMJ. https://jurnal.umj.ac.id/index.php/hol istika/article/download/3094/278 
Dongeng Dalam Membentuk Karakter Islami Anak

Rausyan Fikr. Vol. 16 No. 2 September 2020. ISSN. 1979-0074 e-ISSN. 9772580594187 